\author{
Г.О. СЛАБКИЙ, Ю.Ю. ГАБОРЕЦЬ, О.О. ДУДІНА
}

\title{
АНАЛІЗ РЕЗУЛЬТАТИВНОСТІ РЕГІОНАЛІЗАЦІЇ ПЕРИНАТАЛЬНОЇ ДОПОМОГИ ЖІНКАМ В УКРАЇНІ
}

\author{
ДУ «Український інститут стратегічних досліджень Міністерства охорони здоров’я \\ України», м. Київ, Україна
}

\begin{abstract}
Мета: вивчити та проаналізувати результативність регіоналізації перинатальної допомоги жінкам в Україні.
Матеріали та методи. Дослідження результативності регіоналізації перинатальної допомоги проведено із застосуванням даних державної і галузевої статистики, перинатального аудиту за BABIES-MATRICA за 20112015 рр., моніторингу та оцінки РПД за даними 2014-2015 рр., SWOT-аналізу. Застосовано методи: статистичний, грасрічного зображення.

Результати. Регіоналізація перинатальної допомоги має позитивні результати щодо стану здоров'я жінок. Так, рівень абортів скоротився з 17,0 до 9,8 на 1000 жінок фрертильного віку при співвідношенні абортів та живонароджених дітей 1:3,9. При цьому відмічається тенденція до збільшення частки абортів, які проводяться безпечними методами. Збільшилася частка жінок із вадами серця (61,0\%-66,9\%) та еклампсією і прееклампсією (78,0\%-83,0\%), які народжували в закладах третього рівня. Тенденцію до скорочення мають такі ускладнення, як маткові кровотечі (з 18,59\% до 18,1\%).

Висновки. Отримані дані підтвердили позитивний вплив регіоналізації перинатальної допомоги на показники здоров'я матерів в Україні.
\end{abstract}

КЛЮчОВІ СЛОВА: перинатальна допомога, моніторинг, регіоналізація, результативність, жінки.

Відповідно до рекомендацій ВООЗ [4;5], в Україні, починаючи з 2011 р., проводиться реформа системи пренатальної допомоги [3]. Трирівнева система перинатальної допомоги створена в усіх регіонах України, за винятком Волинської, Закарпатської і Чернігівської областей, де відсутні заклади перинатальної допомоги (ЗПД) III рівня. При цьому у Дніпропетровській, Донецькій, Житомирській, Запорізькій, Кіровоградській, Луганській, Полтавській, Рівненській, Харківській, Хмельницькій областях та м. Києві за сприяння Національного проекту «Нове життя - нова якість охорони материнства та дитинства» організовані і фрункціонують оснащені необхідною високотехнологічною лікувально-діагностичною апаратурою i підготовленим для надання висококваліфрікованої перинатальної допомоги жінкам і новонародженим $з$ ризиком розвитку перинатальної патології та смертності перинатальні центри III-го рівня. На даний час не закінчено будівництво запланованих перинатальних центрів у Волинській, Львівській, Тернопільській, Черкаській та Чернівецькій областях [1;2].

Мета роботи: вивчити та проаналізувати результативність регіоналізації перинатальної допомоги (РПД) в Україні.

Матеріали та методи. Дослідження результативності РПД проведено із застосуванням даних

( Г. Г.О. Слабкий, Ю.Ю. Габорець, О.О. Дудіна, 2016 державної і галузевої статистики, перинатального аудиту за BABIES-MATRICA за 2011-2015 рр., моніторингу та оцінки РПД за даними 2014-2015рр., SWOT-аналізу. Застосовано статистичний метод та метод грасрічного зображення.

Результати дослідження та їх обговорення. Одним з індикаторів РПД визначено зниження рівня штучних абортів, які належать до найбільш вагомих чинників, що впливають на фрормування репродуктивного здоров'я.

Виконання заходів Державної програми «Репродуктивне здоров'я нації» на період до 2015 р. та РПД сприяло суттєвому зниженню кількості абортів в Україні - 3 17,0 на 1000 жінок фрертильного віку у 2011 р. до 9,8 у 2015 році. Загальна кількість абортів за цей період зменшилась на 65,2 тис. (рис. 1). Однак, незважаючи на позитивну динаміку частоти абортів у жінок фрертильного віку, в Україні цей показник у 2-6 разів вищий, ніж у Канаді, Нідерландах, Німеччині, Іспанії.

У всьому світі статистика відношення аборту до живонароджених виглядає як 1:7, в Україні 3 2001 р. частота пологів почала перевищувати частоту абортів, проте співвідношення аборту до живонароджених становить лише 1:3,9. Позитивною $\epsilon$ і динаміка частоти абортів на 100 пологів - 31,7 у 2011 p. i 25,66 у 2015 p. (рис. 2).

При цьому зберігається регіональна диспропорція цього показника - від 4,73 на 1000 жінок 


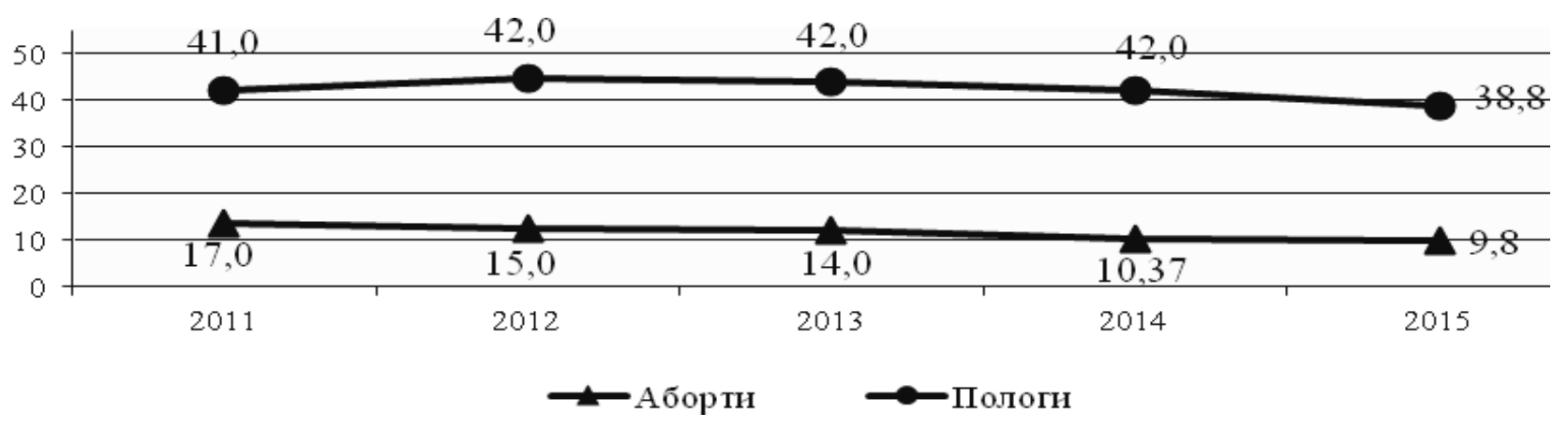

Puc. 1. Динаміка частоти пологів і абортів в Україні у 2011-2015 рр. (на 1000 жінок фертильного віку)

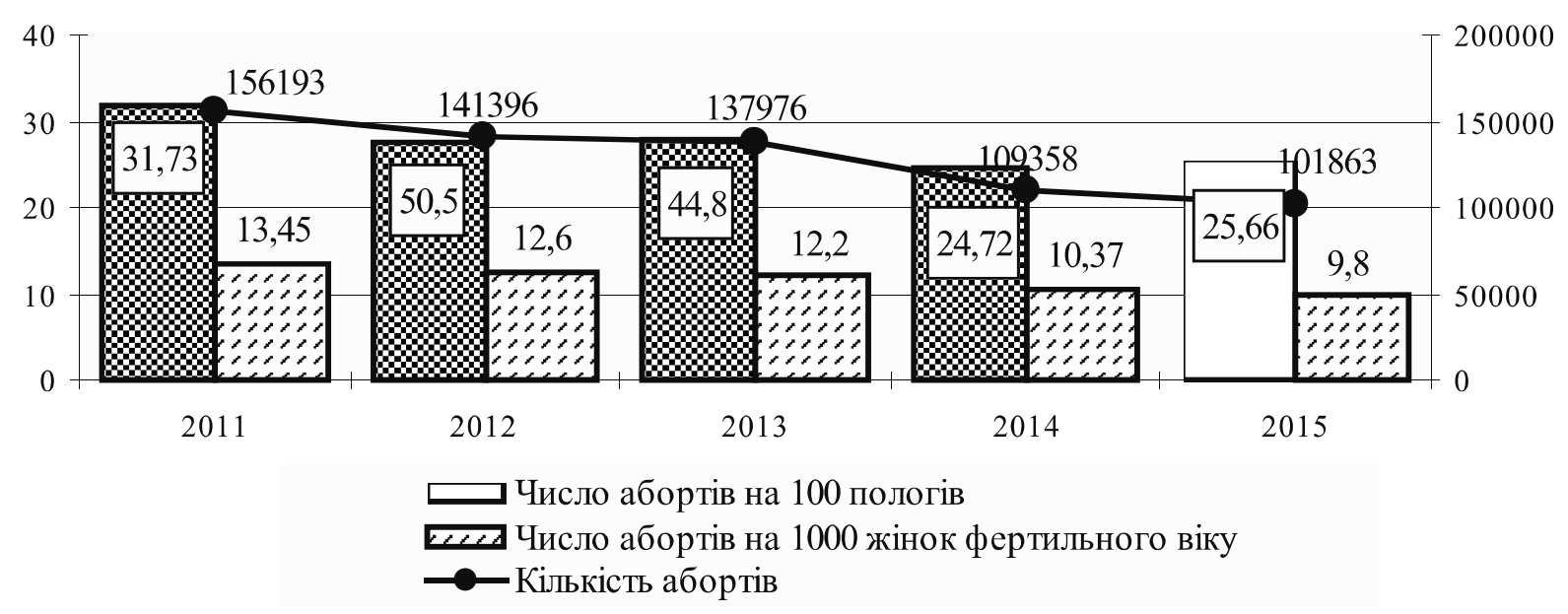

Puc. 2. Динаміка частоти абортів в Україні у 2011-2015 рр.

фертильного віку у Тернопільській, 5,4 у Рівненській, 6,45-6,54 у Івано-Франківській і Сумській до 14,07-15,96 у Вінницькій, Київській і Житомирській областях (рис. 3).

Згідно з ключовими міжнародними документами та положеннями, аборт не є методом планування сім'ї, але в разі прийняття жінкою рішення про переривання вагітності у термінах, дозволених законодавством, послуги мають бути надані з використанням безпечних методик та 3 дотриман- ням репродуктивних прав жінки. При цьому кюреточний метод аборту належить до небезпечних методів, у той час як медикаментозний, методи вакуум-аспірації та екскохлеації - до безпечних. Упродовж останніх років сорормувалася тенденція до зменшення кількості абортів, проведених небезпечними методами переривання вагітності, при позитивній динаміці їх співвідношення: якщо у 2011 р. на один небезпечний аборт припадало 3,54 безпечного, то у 2015 р. - 5,9 (рис. 4).

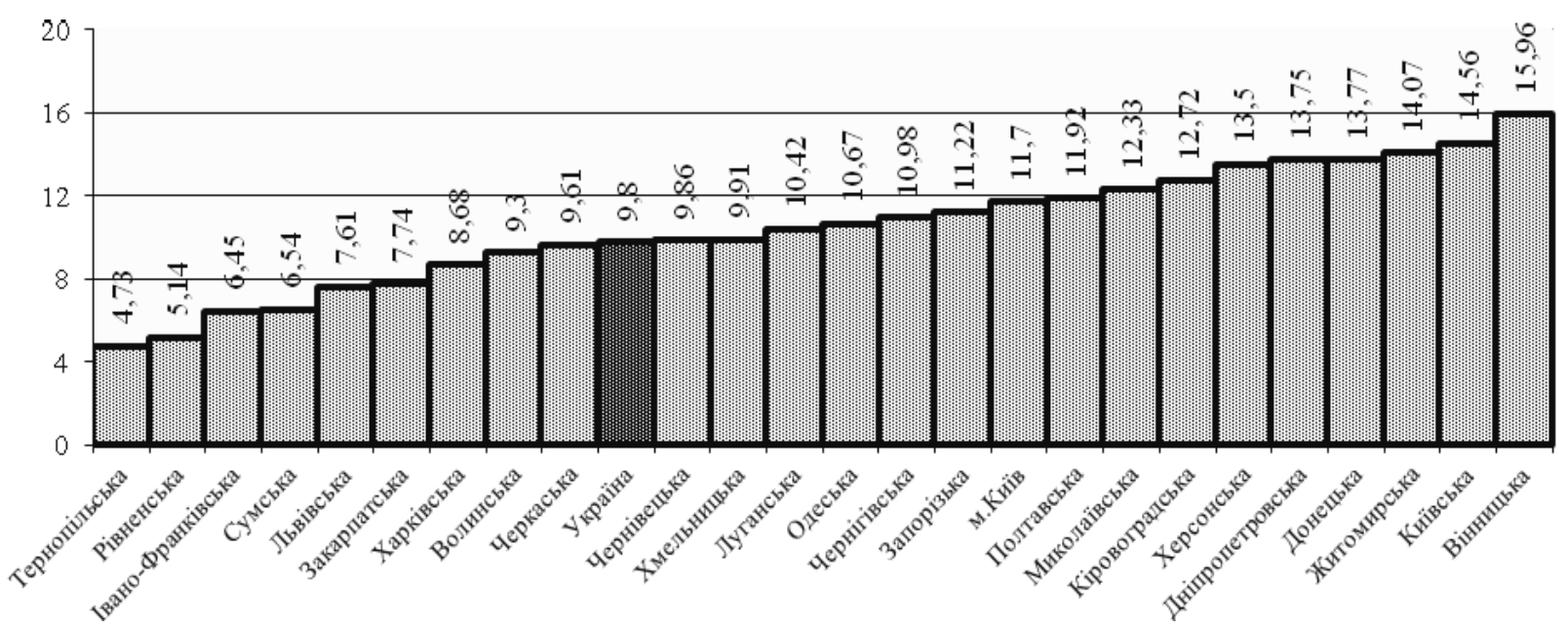

Puc. 3. Ранговий розподіл адміністративних територій України за показниками абортів, 2015 р.(на 1000 жінок фертильного віку) 


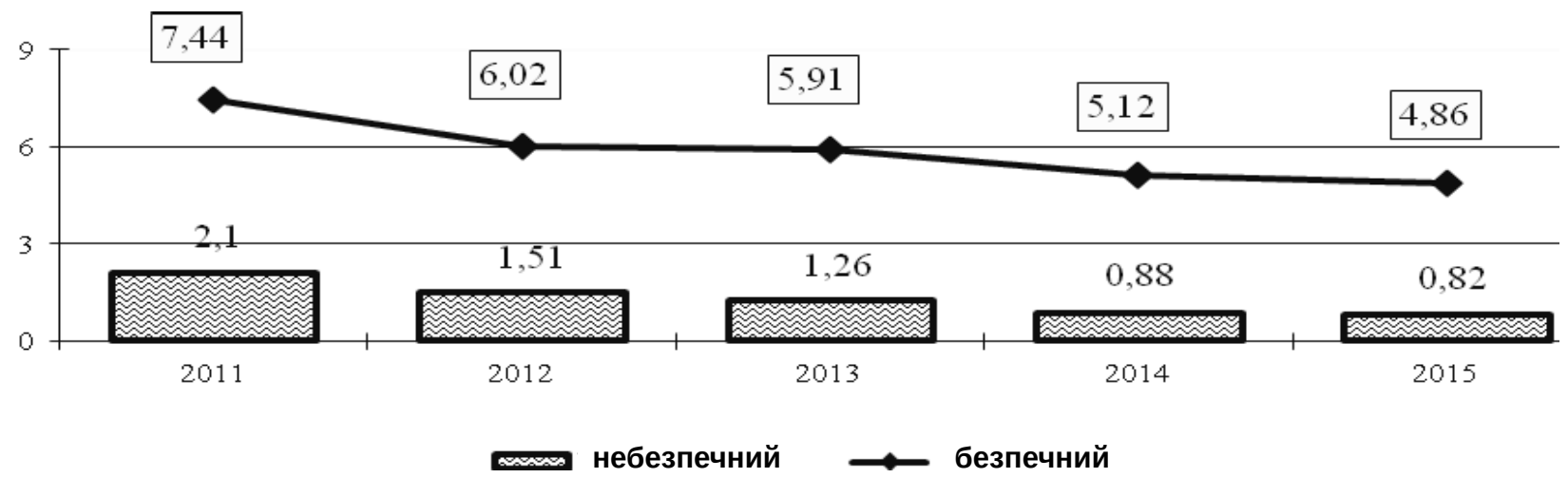

Puc. 4. Динаміка небезпечного і безпечного методів переривання вагітності до 12 тижнів у 2011-2015 рр. (кількість абортів на 1000 жінок фертильного віку)

Важливим завданням РПД є профрілактика перинатальних ускладнень у жінок з перинатальним ризиком, важкою екстрагенітальною патологією і забезпечення їм доступу до спеціалізованої та високоспеціалізованої перинатальної допомоги. Виконання цього завдання можливе за умови розробки регіональних схем руху (маршруту) вагітних, породіль, роділь і новонароджених з ризиком материнської і перинатальної патології і смертності в заклади перинатальної допомоги відповідного рівня.

Відповідно до відпрацьованих з урахуванням функцій та можливостей ЗПД різних рівнів спеціалістами робочої групи МОЗ України алгоритмів ведення вагітних із перинатальним ризиком, можна вважати достатнім розродження в умовах 3ПД III рівня 50,0\% вагітних 3 вадами серця, 25-30\% з хворобами системи кровообігу, 90\% і більше з цукровим діабетом, а у ЗПД II-III рівнів 90\% і більше з прееклампсією та еклампсією, антенатальною загибеллю плода.

У цілому в Україні за даними МіО РПД 20142015 рр. забезпечена оптимальна доступність до високоспеціалізованої високотехнологічної перинатальної допомоги під час пологів вагітних з вадами серця (ІК у ЗПД III рівня 61,0\%-66,9\%) та 3 хворобами системи кровообігу (IK 50,5\%-47,0\%) (табл. 1).

Характерно, що орієнтовні показники IK розроджень вагітних з вадами серця та хворобами системи кровообігу досягнуто у переважній більшості регіонів, де функціонують ЗПД III рівня, за винятком Вінницької, Київської, Миколаївської і Херсонської областей. При цьому у ЗПД І рівня розроджено $\geq 30 \%$ вагітних з вадами серця Волинської, Житомирської, Чернігівської і Черкаської областей та $\geq 40 \%$ вагітних із хворобами системи кровообігу Житомирської, Закарпатської і Херсонської областей.

Низьким, таким, що не відповідає медичним стандартам супроводу та надання допомоги па- цієнткам, залишається IК розроджень вагітних 3 цукровим діабетом у ЗПД III рівня (46,3\%-46,9\%). При цьому зберігається регіональна дисоціація IK у зПД III рівня розроджень вагітних із цукровим діабетом від 90\%-100\% у Житомирській, Запорізькій, Івано-Франківській, Кіровоградській, Львівській, Полтавській, Сумській, Тернопільській та Харківській областях до менше 40,0,\% у Дніпропетровській, Миколаївській, Рівненській, Черкаській областях та м. Києві. Незадовільною залишається доступність розроджень вагітних з цукровим діабетом Закарпатської, Черкаської і Чернівецької областей, де у ЗПД I рівня розроджено $28,1 \%$, 16,7\% і 31,6\% відповідно вагітних з цією патологією.

Медичним стандартом супроводу та надання стаціонарної допомоги вагітним із важкими формами прееклампсії та еклампсії передбачена госпіталізація для розродження цих пацієнток у ЗПД II-III рівнів. У 2014-2015 рр. загалом в Україні ІК цих пацієнток у ЗПД II-III рівнів становив 78,0\% та 83,\%, що можна вважати недостатнім (табл. 2).

При цьому 90,0\% і більше вагітних з важкими формами прееклампсії та еклампсії було розроджено у ЗПД II-III рівнів Дніпропетровської, Одеської, Полтавської, Сумської, Тернопільської, Харківської областей та м. Києва. Проблемним залишається питання забезпечення маршрутизації вагітних із важкими формами прееклампсії та еклампсії у Закарпатській, Київській та Чернігівській областях, де у ЗПД II-III рівнів розроджено цих пацієнток 30,4\%, 33,3\% та 47,4\% відповідно.

Відповідно до алгоритму ведення вагітних 3 перинатальним ризиком, розродження вагітних 3 антенатальною загибеллю плода здійснюється у ЗПД II-III рівнів. За даними моніторингу 20142015 рр., у ЗПД II-III рівнів було розроджено 75,1\%$72,2 \%$ пацієнток. Достатньою можна вважати роботу із забезпечення маршруту пацієнток із цією патологією лише у м. Києві, Дніпропетровській, Полтавській, Сумській і Харківській областях, де у ЗПД І рівня було розроджено менше 10\% пацієнток 
Таблиця 1. Моніторингові показники доступності високоспеціалізованої перинатальної допомоги розроджень вагітних у ЗПД III рівня у 2014-2015 рр., \% від загальної кількості у регіоні обслуговування

\begin{tabular}{|c|c|c|c|c|c|c|}
\hline \multirow[t]{2}{*}{$\begin{array}{c}\text { Адміністративно- } \\
\text { територіальна одиниця }\end{array}$} & \multicolumn{2}{|c|}{$\begin{array}{c}\text { Розроджено вагітних із } \\
\text { вадами серця }\end{array}$} & \multicolumn{2}{|c|}{$\begin{array}{c}\text { Розроджено вагітних } \\
\text { із хворобами системи } \\
\text { кровообігу }\end{array}$} & \multicolumn{2}{|c|}{$\begin{array}{c}\text { Розроджено вагітних із } \\
\text { цукровим діабетом }\end{array}$} \\
\hline & 2014 p. & 2015 p. & 2014 p. & 2015 p. & 2014 p. & 2015 p. \\
\hline Вінницька & 39,1 & 47,3 & 17,1 & 19,8 & 83,9 & 66,7 \\
\hline Волинська & 0,0 & 0,0 & 0,0 & 0,0 & 0,0 & 0,0 \\
\hline Дніпропетровська & 82,6 & 87,9 & 49,5 & 66,5 & 32,8 & 34,5 \\
\hline Житомирська & 50,9 & 68,6 & 47,7 & 58,9 & 88,1 & 95,9 \\
\hline Закарпатська & 0,0 & 0,0 & 0,0 & 0,0 & 0,0 & 0,0 \\
\hline Запорізька & 86,2 & 99,1 & 32,9 & 59,2 & 77,1 & 91,7 \\
\hline Івано-Франківська & 95,5 & 100,0 & 90,2 & 96,1 & 100,0 & 97,5 \\
\hline Київська & 0,0 & 39,5 & 22,0 & 19,4 & 65,1 & 82,4 \\
\hline Кіровоградська & 82,1 & 53,3 & 75,5 & 83,6 & 95,5 & 100,0 \\
\hline Львівська & 100,0 & 97,4 & 72,1 & 76,3 & 96,9 & 91,7 \\
\hline Миколаївська & 0,0 & 20,0 & 0,0 & 1,6 & 0,0 & 18,6 \\
\hline Одеська & 81,6 & 85,2 & 65,8 & 58,0 & 78,0 & 80,8 \\
\hline Полтавська & 86,2 & 82,7 & 79,6 & 84,7 & 100,0 & 100,0 \\
\hline Рівненська & 100,0 & 90,0 & 56,6 & 48,0 & 38,2 & 33,3 \\
\hline Сумська & 90,9 & * & 34,9 & 67,7 & 92,9 & 100,0 \\
\hline Тернопільська & 73,0 & 91,5 & 58,9 & 62,8 & 77,8 & 100,0 \\
\hline Харківська & 99,6 & 99,0 & 81,3 & 88,1 & 97,1 & 96,3 \\
\hline Херсонська & 11,8 & - & 5,6 & 7,8 & 46,4 & 64,4 \\
\hline Хмельницька & 49,2 & 79,7 & 27,8 & 23,8 & 49,1 & 48,0 \\
\hline Черкаська & 47,8 & 63,0 & 38,2 & 34,2 & 20,4 & 29,6 \\
\hline Чернівецька & 68,6 & 41,3 & 78,4 & 57,7 & 100,0 & 57,9 \\
\hline М. Київ & 40,8 & 42,4 & 32,4 & 25,0 & 9,1 & 5,7 \\
\hline Усього & 63,2 & 66,9 & 50,5 & 47,0 & 46,3 & 46,9 \\
\hline
\end{tabular}

від загальної кількості розроджених пацієнток з антенатальною загибеллю плода в регіоні. Потребує доопрацювання питання забезпечення маршрутів цих пацієнток у Волинській, Житомирській, Закарпатській, Київській, Херсонській, Хмельницькій, областях, де цей показник перевищує 50\%.

Показники процесу есрективності РПД, які залежать від методичного регулювання організації перинатальної допомоги у регіоні обслуговування, вивчалися і за даними частоти кесаревого розтину переведених із ЗПД І-ІІ рівнів у ЗПД ІІІ-го рівня пацієнтів та проведених дистанційних і виїзних консультацій.

За даними державної статистики, в Україні останнім часом частота кесаревих розтинів має тенденцію до зростання (17,6\% у 2011 р. і 18,5\% у 2015 р.), ВШ 3 95\% ДІ 1,18 (1,17-1,2). Водночас у державах Західної Європи та США спостерігається зниження частоти кесаревого розтину, що в першу чергу пов'язують з природним розродженням жінок із рубцем на матці. За даними надійних досліджень, збільшення частоти кесаревого розтину вище 12,0\% недоцільне, оскільки не впливає на зниження перинатальної патології і смертності. За даними МіО РПД, частота кесаревого розтину в цілому по Україні становила 17,7\% у 2014 р. і 18,3\% у 2015 р. із різницею цього показника у 2015 р. від 20,0\%-23,8\% у Івано-Франківській, Одеській, Харківській, Чернігівській до $\leq 16,0 \%$ у Львівській, Черкаській, Полтавській, Вінницькій областях (рис. 5).

Даний показник безпосередньо залежить від рівня ЗПД - найнижчий у закладах первинної перинатальної допомоги і найвищий - у закладах третинної перинатальної допомоги. Аналогічна закономірність виявлена і за даними моніторингу: частота кесаревого розтину в цілому в Україні у ЗПД І рівня становила у 2014-2015 рр. відповідно 12,6-13,0\%, вторинного - 18,2-19,3\%, третинного 27,1-27,6\% і характерна для майже усіх регіонів, за винятком Чернівецької області, де показник кесаревого розтину у ЗПД І рівня вищий, ніж у ЗПД ІІ рівня (109\% і 8,3\%), та м. Києва, де частота кесаревого розтину у 2015 р. у ЗПД ІІ рівня становила 20,1\%, а у ЗПД ІІІ рівня - 15,4\%.

Слід зазначити, що ефективність РПД є неоднорідною. Так, частота кесаревого розтину відповідає функціональним можливостям у ЗПД І рівня $(\leq 10,0 \%)$ Львівської, Сумської, Полтавської, Тернопільської областей, у ЗПД ІІ рівня ( $\leq 15,0 \%)-$ Закарпатської, Полтавської, Рівненської і Чернівецької областей, у ЗПД ІІІ рівня ( $\leq 25,0 \%)$ - Дніпропетровської, Житомирської, Запорізької, Хмель- 
Таблиця 2. Моніторингові показники доступності високоспеціалізованої перинатальної допомоги розроджень вагітних у ЗПД II-III рівнів, 2014-2015 рр., \% від загальної кількості у регіоні обслуговування

\begin{tabular}{|c|c|c|c|c|}
\hline \multirow{2}{*}{$\begin{array}{c}\text { Адміністративно- } \\
\text { територіальна одиниця }\end{array}$} & \multicolumn{2}{|c|}{$\begin{array}{l}\text { Розроджено вагітних із важкими } \\
\text { фрормами прееклампсії, еклампсії }\end{array}$} & \multicolumn{2}{|c|}{$\begin{array}{c}\text { Розроджено вагітних } \\
\text { з антенатальною загибеллю плода }\end{array}$} \\
\hline & 2014 p. & 2015 p. & 2014 p. & 2015 p. \\
\hline Вінницька & 76,3 & 71,1 & 62,9 & 53,2 \\
\hline Волинська & 60,7 & 60,9 & 41,9 & 37,1 \\
\hline Дніпропетровська & 96,2 & 97,9 & 91,8 & 91,5 \\
\hline Житомирська & 38,6 & 50,8 & 40,3 & 32,3 \\
\hline Закарпатська & 60,2 & 30,4 & 55,9 & 35,0 \\
\hline Запорізька & 89,8 & 80,9 & 70,69 & 79,2 \\
\hline Івано-Франківська & 90,0 & 83,9 & 82,5 & 86,8 \\
\hline Київська & 60,6 & 33,3 & 61,9 & 47,9 \\
\hline Кіровоградська & 83,6 & 67,7 & 60,3 & 56,4 \\
\hline Львівська & 78,0 & 84,7 & 83,6 & 82,7 \\
\hline Миколаївська & 59,8 & 66,7 & 40,3 & 63,4 \\
\hline Одеська & 97,2 & 97,1 & 85,3 & 74,6 \\
\hline Полтавська & 100,0 & 100,0 & 90,2 & 90,2 \\
\hline Рівненська & 67,6 & 79,6 & 65,5 & 56,60 \\
\hline Сумська & 100,0 & 90,5 & 96,4 & 94,2 \\
\hline Тернопільська & 92,3 & 93,5 & 88,7 & 87,7 \\
\hline Харківська & 96,9 & 97,7 & 96,63 & 97,7 \\
\hline Херсонська & 87,9 & 65,4 & 52,9 & 48,5 \\
\hline Хмельницька & 60,6 & 72,4 & 50,7 & 36,7 \\
\hline Черкаська & 42,0 & 53,2 & 51,4 & 54,02 \\
\hline Чернівецька & 61,5 & 65,9 & 66,0 & 62,8 \\
\hline Чернігівська & 95,0 & 47,4 & 83,6 & 72,6 \\
\hline м. Київ & 100,0 & 100,0 & 100,0 & 100,0 \\
\hline Усього & 78,0 & 83,0 & 75,1 & 72,2 \\
\hline
\end{tabular}

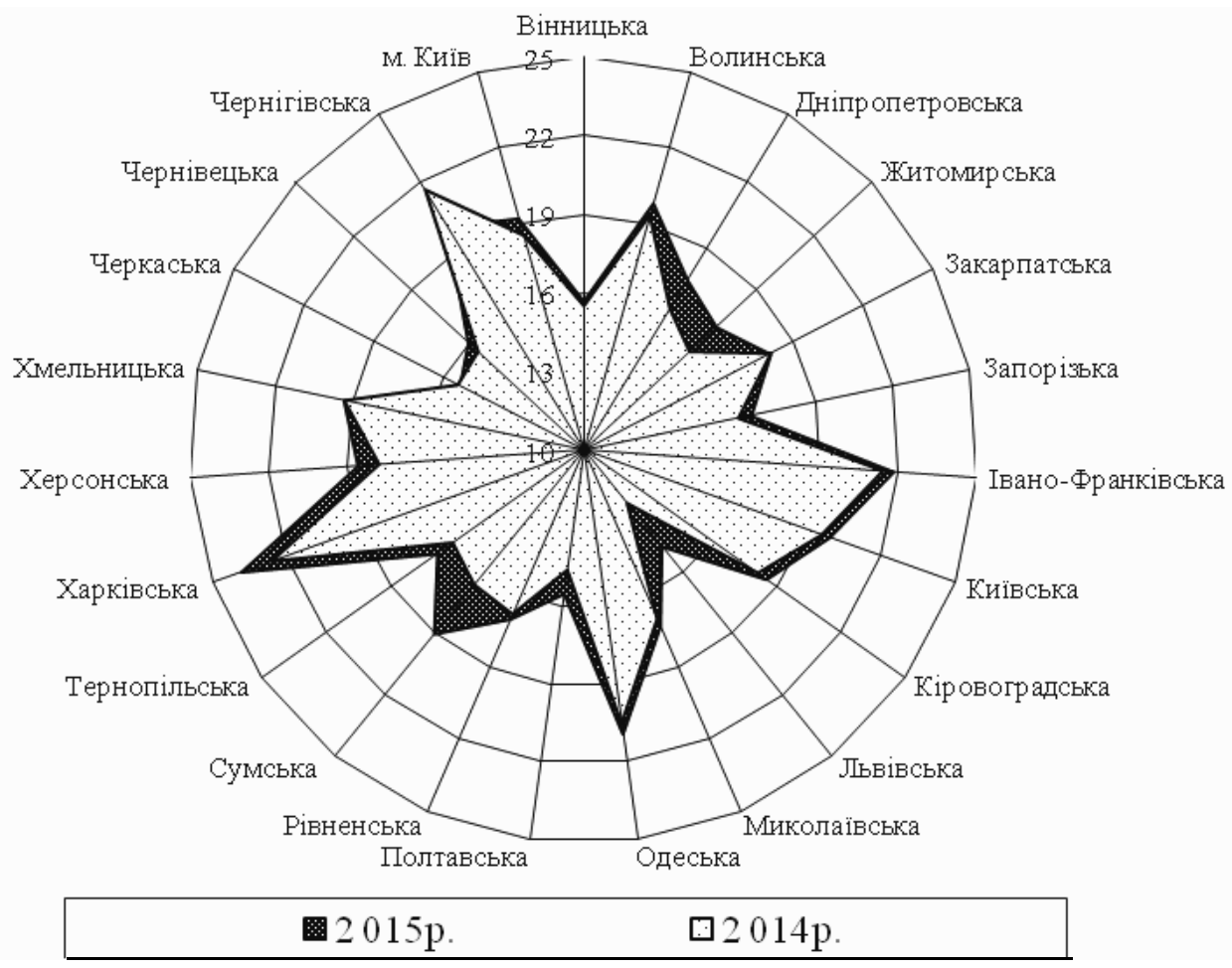

Рис. 5. Частота пологів шляхом кесаревого розтину в Україні у 2014-2015 рр., \% 
ницької, Чернівецької областей. Надвисокими для ЗПД відповідного рівня утримуються показники кесаревого розтину у ЗПД І рівня ( $\geq 15 \%)$ Волинської, Закарпатської, Івано-Франківської, Миколаївської, Хмельницької і Чернігівської областей, у ЗПД ІІ рівня ( $\geq 20 \%)$ Волинської, Закарпатської, ІваноФранківської, Київської, Одеської, Херсонської, Хмельницької, Чернівецької областей та м. Києва, а майже кожна третя вагітна розроджена шляхом кесарева розтину у ЗПД ІІІ рівня Вінницької, ІваноФранківської, Київської, Одеської, Полтавської,
Херсонської областей. Така неоднорідність частоти кесаревого розтину потребує вивчення шляхом проведення клінічних аудитів.

Впровадження РПД та рекомендованих ВООЗ перинатальних технологій із доведеною ефективністю, зокрема родопомочі, орієнтованої на участь сім'ї, демедикалізації пологів, ведення партограми тощо, сприяло забезпеченню достатньої частоти нормальних пологів - 68,5\% у 2011 р. і 67,97\% у 2015 р. (рис. 6).

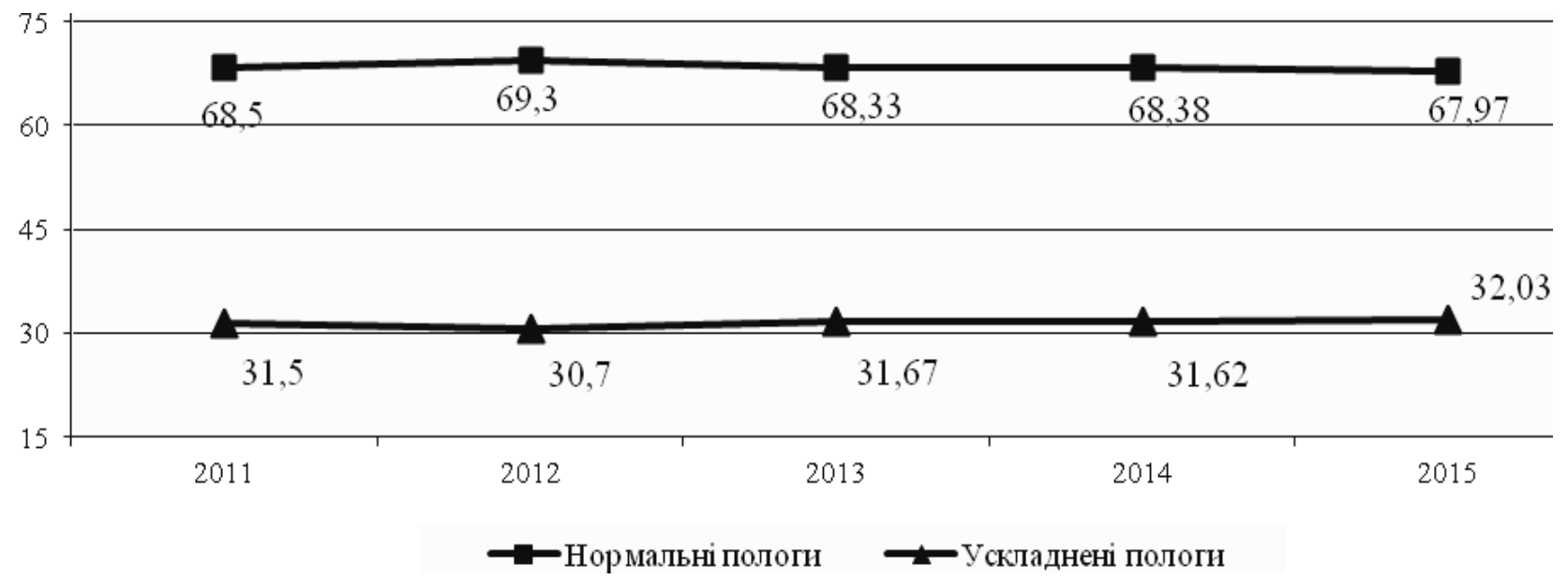

Puc. 6. Динаміка частоти нормальних та ускладнених пологів в Україні у 2011-2015 рр. (на 100 пологів)

Як і в попередні роки, спостерігалася поляризація показника ускладнених пологів від 39,08\% у Дніпропетровській, 38,14\% у Хмельницькій, 37,88\% у Житомирській, до близько 26,12\%-24,65\% у Рівненській, Черкаській та Львівській областях.

Частим і важким ускладненням вагітності та пологів, яке очолює так звану «велику п'ятірку» причин материнської смертності в усьому світі, у тому числі в Україні, $€$ акушерські кровотечі. Результатом ефективності РПД та технології клінічного протоколу «Нормальні пологи» стосовно запропонованого Міжнародною фредерацією акушерів-гінекологів ведення третього періоду пологів $€$ тенденція до зменшення частоти акушерських кровотеч із 18,59 у 2011 р. до 18,1 у 2015 р., ВШ $з$ 95\% ДІ 09 (0,9-1,0) та кровотеч у послідовому і післяпологовому періодах - 3 9,23 до 8,18, ВШ $з$ 95\% ДІ 0,9 (0,8-0,9) відповідно (рис. 7).

При позитивній динаміці частоти кровотеч у послідовому та післяпологовому періодах загалом по Україні такі показники були все ще високими (вище 11,00 на 1000 пологів) у ЗПД Житомирської

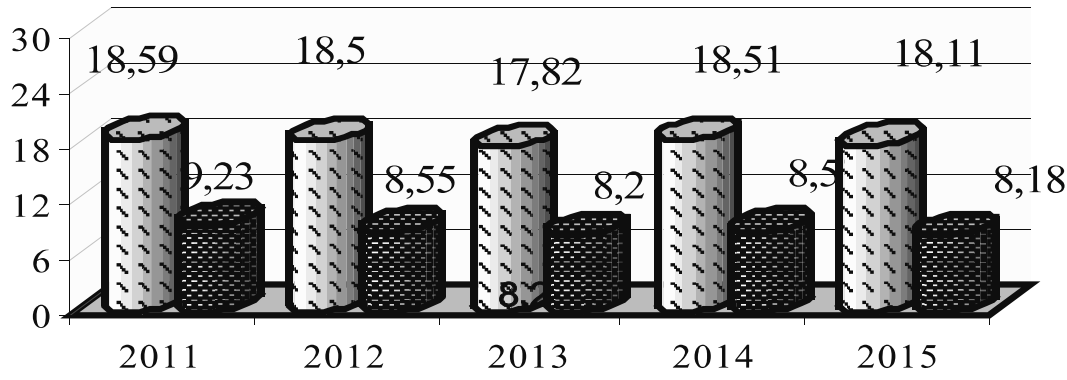

Ш Кровотеча

Кровотеча в послідовому і післяродовому періодах

Puc. 7. Динаміка акушерських кровотеч в Україні за 2011-2015 рр. (на 1000 пологів) 
$(11,77)$, Закарпатської $(11,87)$, Херсонської $(14,03)$ та Черкаської $(12,82)$ областей. Лише в ЗПД м. Києва та Львівської області зафріксовано відносно низькі показники кровотеч у послідовому і післяпологовому періодах $(3,39)$.

За даними досліджень, впровадження сучасних перинатальних технологій сприяє зниженню таких важких ускладнень пологів і післяпологового періоду, як розриви матки, промежини та родовий сепсис і розлита післяпологова інфекція. Однак, після суттєвого зниження цих ускладнень у 2000-2003 рр., останніми роками стабілізувалися показники розривів промежини III-IV ступенів на рівні 0,1-0,05 на 1000 пологів, розривів матки - 0,04-0,01, родового сепсису і розлитої післяпологової інфрекції - 0,1-0,03.

\section{Висновки}

У ході дослідження встановлено, що РПД має позитивні результати щодо стану здоров'я жінок. Так, рівень абортів скоротився з 17,0 до 9,8 на 1000 жінок фрертильного віку при співвідношенні абортів та живонароджених дітей 1:3,9. При цьому відмічається тенденція до збільшення частки абортів, які проводяться безпечними методами. Збільшилася частка жінок з вадами серця (61,0\%-66,9\%) та еклампсією і прееклампсією (78,0\%-83,0\%), які народжували в закладах третього рівня. Тенденцію до скорочення мають такі ускладнення, як маткові кровотечі (з 18,59\% до 18,1\%).

Перспективи подальших досліджень пов'язані з вивченням ефективності РПД при наданні медичної допомоги новонародженим дітям.

\section{Список літератури}

1. Дудіна О. О. Динаміка стану репродуктивного з здоров'я населення / О. О. Дудіна, О. В. Лукьянчук // Щорічна доповідь про стан здоров'я населення, санітарно-епідемічну ситуацію та результати діяльності системи охорони здоров'я України. 2015 рік. - Київ, 2016. - С. 88-108.

2. Дудіна О. О. Деякі питання доступності високоспеціалізованої перинатальної допомоги в Україні / О. О. Дудіна, Ю. Ю. Габорець // Україна. Здоров'я нації. - 2016. - № 4 (40). - С. 100-105.

3. Національніпідходидовпровадження системи регіоналізаціїперинатальної допомогив Україні/МОЗУкраїни; заред. Р. О. Моісеєнко. - Київ, 2012. - 135 с.

4. Основная дородовая, перинатальная и постнатальная помощь : материалы учебн. семинара. - Женева : ЕРБ ВОЗ, 2002 [Электронный ресурс]. - Режим доступа : http://medical-diss.com. - Название с экрана.

5. Перша глобальна стратегія ВООЗ в області репродуктивного здоров>я [Електронний ресурс]. - Режим доступу : http://whqlibdoc.who.int. - Назва з екрану.

\section{References}

1. Dudina O.O., \& Lukyanchuk, O.V. (2016). Dynamika stanu reproduktyvnoho zdorovya naselennya [Dynamics of the population reproductive health protection]. Shchorichna dopovid pro stan zdorovya naselennya, sanitarno-epidemichnu sytuatsiyu ta rezultaty diyalnosti systemy okhorony zdorovya Ukraiiny. 2015 - Annual report on the state of health, sanitary and epidemic situation and the performance of the health care system in Ukraine. (pp. 88-108). Kyiv [in Ukrainian].

2. Dudina, O.O., \& Haborets, Yu.Yu. (2016). Deyaki pytannya dostupnosti vysokospetsializovanoi perynatalnoi dopomohy v Ukraini [Some issues of availability of highly-specialized perinatal help in Ukraine]. Ukraina. Zdorovya natsii. - Ukraine. Health of the Nation, 4 (40), 100-105 [in Ukrainian].

3. Moiseenko, P.O. (Eds.). (2012). Natsionalni pidkhody do vprovadzhennya systemy rehionalizatsii perynatalnoi dopomohy $v$ Ukraini [National approaches to the introduction of the system of regionalization of perinatal help in Ukraine]. Kyiv [in Ukrainian].

4. Osnovnaya dorodovaya, perinatalnaya i postnatalnaya pomoshch: materialy uchebnogo seminara [The basic prenatal, perinatal and postnatal help: study workshop materials]. (n.d.). medical-diss.com. Retrieved from http://medical-diss.com. [in Russian].

5. Persha hlobalna stratehiya VOOZ v oblasti reproduktyvnoho zdorovya [WHO first global strategy in reproductive health protection]. (n.d.). whqlibdoc.who.int. Retrieved from http://whqlibdoc.who.int. [in Russian].

\section{АНАЛИЗ РЕЗУЛЬТАТИВНОСТИ РЕГИОНАЛИЗАЦИИ ПЕРИНАТАЛЬНОЙ ПОМОЩИ ЖЕНЩИНАМ В УКРАИНЕ}

Г.А. Слабкий, Ю.Ю. Габорец, Е.А. Дудина

ГУ «Украинский институт стратегических исследований Министертва здравоохранения Украины», г. Киев, Украина

Цель: изучить и проанализировать результативность регионализации перинатальной помощи женщинам в Украине.

Материалы и методы. Исследование результативности регионализации перинатальной помощи проведено с использованием данных государственной и отраслевой статистики, перинатального аудита по BABIES-MATRICA за 2011-2015 гг., мониторинга и оценки регионализации перинатальной помощи по данным 2014-2015 гг., SWOT-анализа. Применялись методы: статистический, графрического изображения.

Результаты. Регионализация перинатальной помощи имеет положительные результаты относительно состояния здоровья женщин. Так, уровень абортов сократился с 17,0 до 9,8 на 1000 женщин фрертильного возраста при соотношении абортов и живорожденных детей 1:3,9. При этом отмечается тенденция к 
увеличению доли абортов, которые проводятся безопасными методами. Увеличилась доля женщин с пороками сердца $(61,0 \%-66,9 \%)$, эклампсией и преэклампсией $(78,0 \%-83,0 \%)$, рожавших в учреждениях третьего уровня. Тенденцию к сокращению имеют такие осложнения, как маточные кровотечения (с 18,59\% до $18,1 \%)$.

Выводы. Полученные данные подтвердили положительного влияние регионализации перинатальной помощи на показатели здоровья матерей в Украине.

КЛЮЧЕВЫЕ СЛОВА: перинатальная помощь, мониторинг, регионализация результативность, женщины.

\section{THE ANALYSIS OF THE EFFECTIVENESS OF REGIONALIZATION IN PERINATAL CARE TO WOMEN IN UKRAINE \\ G.O. Slabkiy, Yu.Yu. Gaborets, O.O. Dudina \\ PE "Ukrainian Institute of Strategic Researches MHC of Ukraine", Kyiv, Ukraine}

Goal of research: to study and analyze the effectiveness of regionalization in perinatal care to women in Ukraine.

Materials and methods. The study of the effectiveness of regionalization in perinatal care was held with the use of the data of State and industry statistics, perinatal audit according to BABIES-MATRICA for the years 20112015 , monitoring and evaluation of the RAP by the years 2014-2015, SWOT-analysis. Applied methods: statistical and graphical images methods were applied.

Results. Regionalization of perinatal care demonstrated positive results as for the state of women's health. Thus, the level of abortions decreased from 17.0 to 9.8 per 1000 women of fertile age, with the ratio of abortions and live births 1:3.9. There exists the tendency to increasing the share of abortions held with the use of safe methods. The proportion of women with impaired heart $(61,0-66,9 \%)$ and eclampsia and preeclampsia $(78,0-83,0 \%)$ who delivered their babies in third-level medical institutions also increased. A tendency to decrease is also registered for such complications as uterine bleeding (18.59\% to $18.1 \%)$.

Conclusions. The data obtained confirmed the positive effect of regionalization in perinatal care on mothers' health in Ukraine.

KEY WORDS: perinatal care, monitoring, regionalization, effectiveness, women.

Рукопис надійшов до редакції 20.12.2016 р.

\section{Відомості про авторів}

Слабкий Геннадій Олексійович - д.мед.н., проф., в.о. директора ДУ «Український інститут стратегічних досліджень Міністерства охорони здоров'я України»; тел. служб.: +38 (044) 576-41-17.

Габорець Юрій Юрійович - к.мед.н., пошукувач ДУ «Український інститут стратегічних досліджень Міністерства охорони здоров'я України»; тел. служб.: +38 (044) 576-41-19.

Дудіна Олена Олександрівна - к.мед.н., с.н.с., завідувач відділення охорони здоров'я матері і дитини ДУ «Український інститут стратегічних досліджень Міністерства охорони здоров'я України»; тел. служб.: +38 (044) 576-41-49. 